\title{
Argulus (Fish Louse) Infections in Fish ${ }^{1}$
}

\author{
Natalie Steckler and Roy P. E. Yanong ${ }^{2}$
}

\section{Introduction}

Argulus species (Family: Argulidae), more commonly known as fish lice, are members of a large group of branchiuran parasites that infest and cause disease in fish. The argulids are crustaceans and are related to crabs, lobsters, and shrimp.

There are approximately 100 different species of Argulus distributed worldwide that, depending upon species, can infest freshwater and saltwater fishes. The three moststudied species, Argulus foliaceus, A. japonicus, and A. coregoni are found in freshwater systems. Infections with these are most common in wild and pond-raised freshwater fish, particularly goldfish, koi, and other cyprinids (carps and minnows); centrarchids (sunfishes) and salmonids (salmon and trout). A. foliaceus has also been found on frogs and toads.

\section{Argulus Biology}

Argulus is dorsoventrally flattened (i.e., flattened from the topside to the underside), has an oval to rounded body covered by a wide carapace (outer protective covering), and two compound eyes (Figure 1). A thin, needle-like "stylet" located in front of the mouth tube is used to pierce the host and help the parasite to ingest bodily fluids. In the adult, two very prominent "suckers," one located on each side of the mouth and stylet, are used to attach to the fish. These suckers develop from hook-like structures in younger stages. Spines and hooks located on their appendages ("legs") assist with movement. Older juveniles and adult Argulus foliaceus are approximately 3-7 mm long x 2-4 mm wide. Females are larger than males and can be identified by short, paired structures at their back end known as seminal receptacles (spermathecae), which receive sperm from the male.

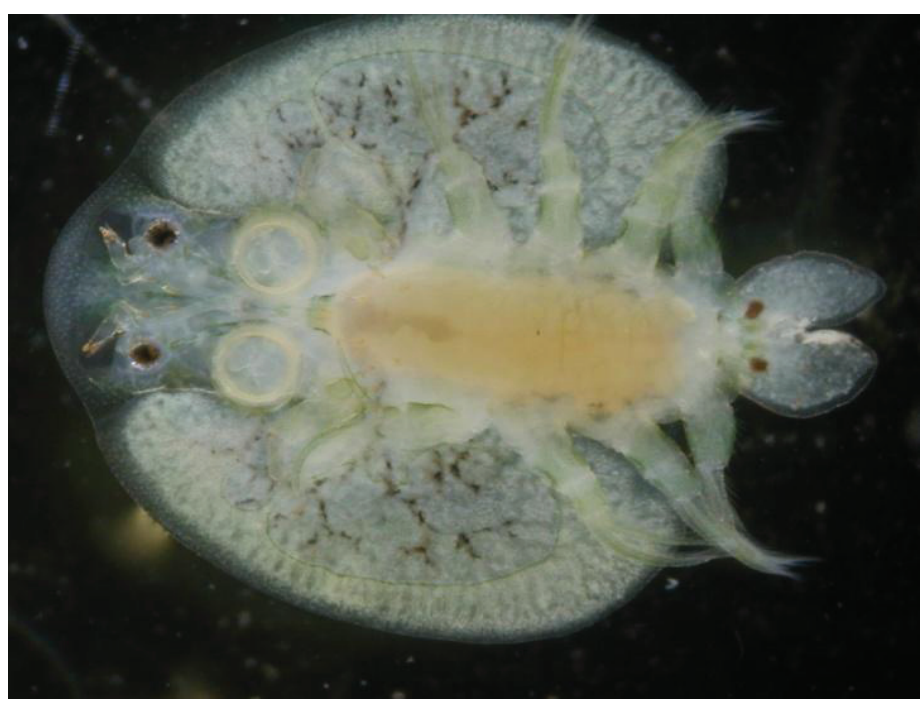

Figure 1. Adult Argulus sp. Note eye spots and round suckers on "head" end, and spermatheca on "back" posterior end.

\section{Argulus Life Cycle}

Argulus has a direct life cycle, meaning it only requires one host (the fish) to completely develop from an egg to a mature, reproducing adult. All crustaceans, including Argulus, develop and grow through a complex series of

1. This document is FA184, one of a series of the Program in Fisheries and Aquatic Sciences, School of Forest Resources and Conservation, Florida Cooperative Extension Service, Institute of Food and Agricultural Sciences, University of Florida. Original publication date November 2012. Visit the EDIS website at http://edis.ifas.ufl.edu.

2. Natalie Steckler, former graduate student, School of Forest Resources and Conservation, Program in Fisheries and Aquatic Sciences; and Roy P. E. Yanong, associate professor and Extension veterinarian, School of Forest Resources and Conservation, Program in Fisheries and Aquatic Sciences, Institute of Food and Agricultural Sciences, University of Florida, Tropical Aquaculture Laboratory, Ruskin, FL 33570. 


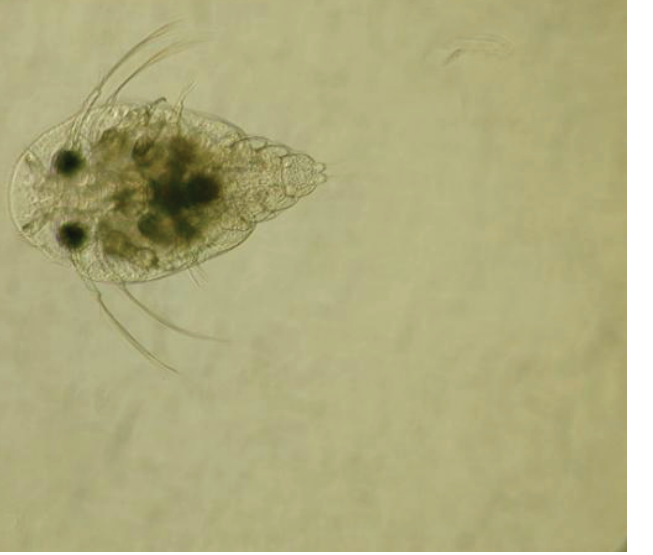

Figure 2. First stage Argulus larvae (metanauplius).

molts (i.e., by shedding their outer surface, or "exoskeleton," which is made of a compound called chitin) and multiple life stages. Unlike copepods-another group of crustacean fish parasites, such as Lernaea (the anchorworm) (see the EDIS publication, Lernaea (Anchorworm) Infections in Fish, forthcoming) - branchiurans continue to molt periodically even after reaching maturity. Some chemical control methods (see Diagnosis and Management) kill the parasite by inhibiting the molting process.

While the branchiuran life cycle averages 30 to 60 days, the actual duration depends on the parasite species and the water temperature. All life stages of both sexes are parasitic-unlike the non-parasitic male anchorworm (Lernaea), a related crustacean copepod parasite (see publication FA185, Lernaea (Anchorworm) Infestations in Fish http://edis.ifas. ufl.edu/fa185) — and Argulus adults can survive for several days off the fish host. After a male/female pair mates, the adult female detaches from the fish host to lay eggs onto hard surfaces and vegetation in the environment. After she releases her eggs, the female returns to the fish host.

The time required for Argulus eggs to hatch will vary, depending upon the species and temperature. Argulus japonicus eggs hatch in 10 days at $35^{\circ} \mathrm{C}$ but require 61 days at $15^{\circ} \mathrm{C}$. At $23^{\circ} \mathrm{C}$ the eggs of a closely related species, $A$. foliaceus, hatch in 17 days, whereas at $20^{\circ} \mathrm{C}$ they hatch in 30 days. If laid in the fall, eggs are capable of overwintering (surviving) until the following spring. In many species, the first stage larvae (known as the "metanauplius") (Figure 2) must find a parasitic host within 2-3 days of hatching or they will die. Once attached to the fish host, juveniles undergo a series of molts (11 molts or 12 "stages" in $A$. foliaceus) until they reach sexual maturity, roughly $30-40$ days after hatching. Juveniles can overwinter within the fish's mucus.

\section{Disease in Fish Caused by Argulus}

Argulus infestations tend to peak in the summer and fall. The lice can be found attached to the skin, gill chamber, and mouth. Localized inflammation occurs at the contact site because of mechanical damage from hooks and spines on the stylet and appendages, and irritation from digestive enzymes. In heavy infestations, the fish lice may be seen all over the skin and fins of the fish and in the water column (Figures 3 and 4). Fish without visible lice may show nonspecific signs of infestation. These include spot or pinpoint hemorrhages, anemia, fin and scale loss, increased mucus production, lethargy, erratic swimming, reduced feeding, hanging at the surface (avoiding swimming into the water column) and poor body condition. Fish may "flash" or rub against surfaces in an attempt to relieve irritation or to remove the parasites. In some cases, there may be no obvious signs of disease other than presence of the parasite.

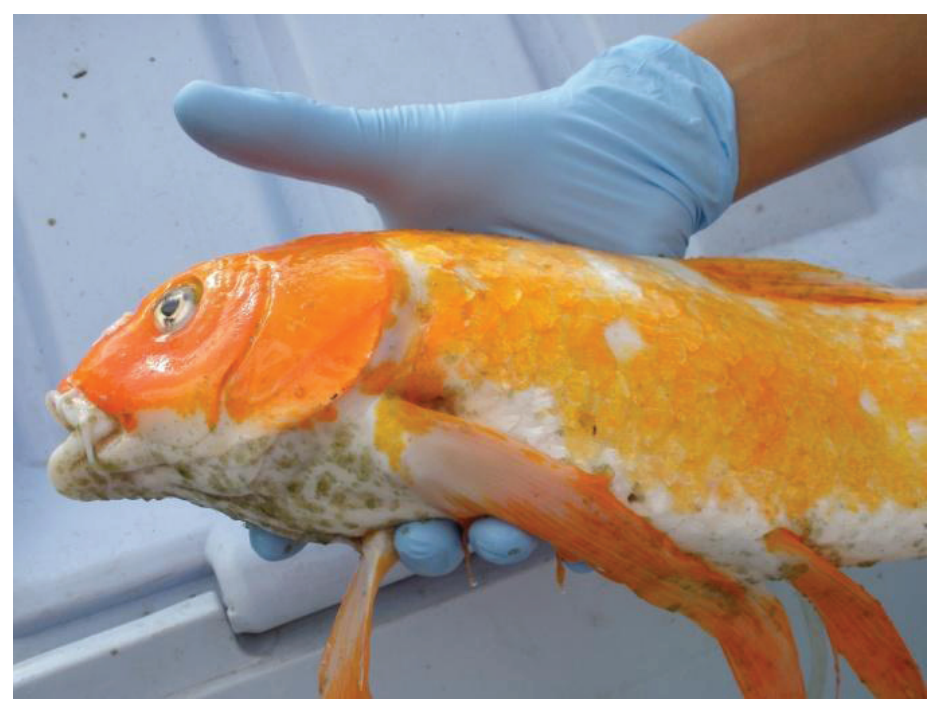

Figure 3. Heavily infested koi. Note readily visible oval parasites in throat (ventral) area of head, as well as others scattered throughout the body.

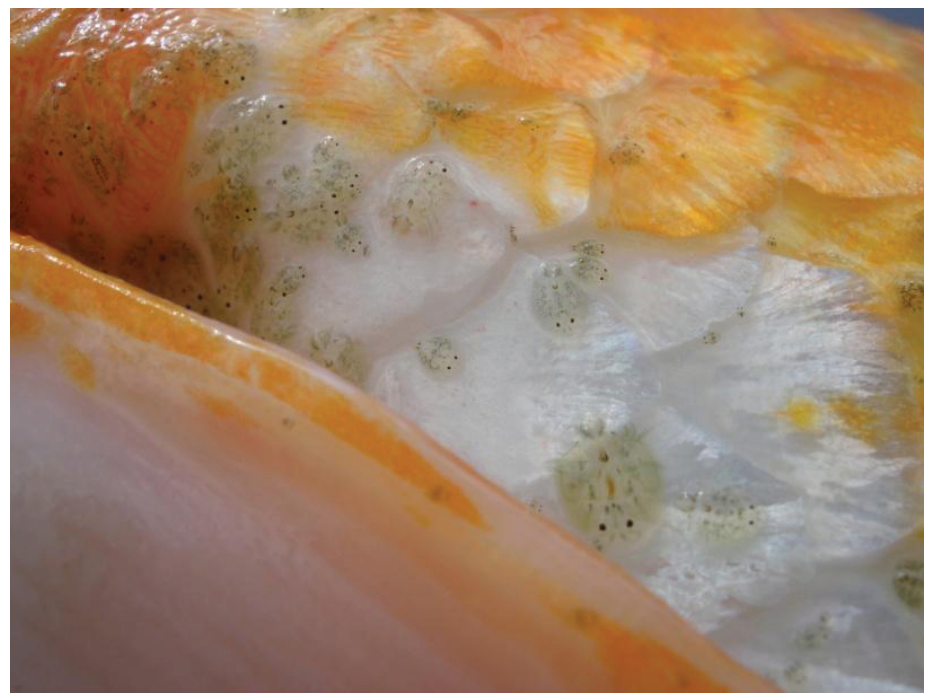

Figure 4. Individual adult and late stage juvenile Argulus are easily seen with the unaided eye 
Although fish may tolerate low and even moderate levels of Argulus with very few signs of disease, localized inflammation and damage at the affected site may lead to secondary infections. The parasite's high reproductive rate can quickly escalate an infection. Severe infestations of hundreds of parasites may debilitate their host by damaging skin and reducing the fish's ability to balance their internal fluids and salt levels. Secondary pathogens, such as the bacteria Aeromonas and the water mold Saprolegnia, are often seen concurrently with Argulus infestations.

Argulus is also capable of acting as a mechanical vector or intermediate host for several fish diseases. The parasite can carry and transmit spring viremia of carp (SVC; see EDIS publication VM-142), a reportable viral disease of koi, common carp, and goldfish, among other hosts. Aeromonas salmonicida, an important bacterial pathogen, has been isolated from Argulus coregoni, and experiments demonstrated higher rates of Aeromonas infection when Argulus are present, but direct transmission from louse to fish has not yet been proven. Argulus can also serve as the intermediate host for several species of nematodes (roundworms).

\section{Diagnosis and Management}

Because of their size, older stages of Argulus can be diagnosed with the naked eye. The parasites are visible moving on the host or swimming in the water. The parasite can also be identified on a wet mount of the affected tissue. Captured fish should be examined quickly because Argulus may rapidly leave the fish once it is disturbed or removed from the water. Filtering water from the system through a fine mesh net may also help capture free-swimming Argulus adults or juveniles for identification. Adults and juvenile stages (which are similar to adults but lack suckers) are relatively easy to identify, but their identification should be verified by a fish health professional.

Drug choice and length of treatment for Argulus infections should take into consideration the life cycle of the parasite, which varies from 30 to 60 days depending on temperature and species. Treatment should target all life stages, including eggs, juveniles, and adults, both on the fish and in the environment. Adult parasites can be manually removed from the affected fish, but this is impractical in many situations and is an incomplete solution because eggs, unattached juveniles, and adults will still be present in the environment. Fish can be moved to a clean tank and treated with the appropriate drugs, while eggs in the original system are eliminated either by cleaning and disinfecting the tank or allowing it to dry completely. However, drying may be difficult in humid areas, and at cooler temperatures eggs can survive much longer time periods. Optimal water quality should be maintained for the duration of any treatments.

Several medications have historically been used for bath treatment of Argulus, but potential resistance to treatment, current availability, legality of use (especially in food fish species), dosage rates and associated costs, and fish species' sensitivities may reduce options. It is best to work with a fish health specialist. There are currently no FDA-approved drugs for the treatment and control of Argulus. Prolonged immersion of an organophosphate pesticide, such as trichlorfon (Dylox ${ }^{\otimes} 80$, Bayer), which acts by disrupting the nervous system, has been an effective treatment when dosed at $0.25-0.50 \mathrm{mg} / \mathrm{L}$ active ingredient, once a week for 4 treatments. Unfortunately Dylox 80 , the only aquatic organophosphate 24 (c) pesticide approved for use in Florida and several other states, is no longer being manufactured. Diflubenzuron (Dimilin ${ }^{\circledast}$, Chemtura) is another pesticide, which acts by interfering with the parasite's molting ("shedding") of the outer skin ("exoskeleton") during growth and development. Diflubenzuron effectively kills both adult and larval stages, but it is a restricted-use pesticide, and applicators must follow label instructions. Other compounds with a similar mechanism of action as diflubenzuron, such as lufenuron (Program ${ }^{\circ}$, Novartis Animal Health) at $0.13 \mathrm{mg} / \mathrm{L}$, have also been used with success. Potassium permanganate $(10 \mathrm{mg} / \mathrm{L}$ for 30 minutes, or $1.3 \mathrm{mg} / \mathrm{L}$ applied twice over 3 days) has been shown to be effective in killing the juvenile and adult stages of freshwater species in several studies. Potassium permanganate is not recommended for use in marine systems. Increased salt concentration does not appear to be effective for the control of Argulus in freshwater, nor does formalin.

Emamectin benzoate (SLICE ${ }^{\mathrm{TM}}$, Merck Animal Health) is an in-feed product that has been shown to experimentally control Argulus infections in goldfish and koi. Emamectin is licensed outside the U.S. for control of sea lice, a saltwater copepod parasite; however, in the U.S. emamectin is an FDA Investigational New Animal Drug (INAD) and, therefore, is currently unavailable for general use. Those interested in its use must contact the manufacturer and enroll in an INAD study (see this site for more information: http://www.fws.gov/fisheries/aadap/slice.htm). Of all the drugs listed above, only potassium permanganate (in freshwater) is legal for use in fish intended for human consumption, and its effectiveness may not be ideal. There are currently no approved products for use in foodfish species. Consequently, it is critical to know where your fish are coming from and to quarantine new fish before introducing 
them to your system. Potentially infested fish should not be mixed with clean fish without a proper quarantine.

Effective management of an Argulus outbreak must include proper identification of the parasite, treatment of all life stages on the fish and in the environment, and proper drug use. Drugs available for treatment of Argulus infestations are limited, so inclusion of a fish health professional in the diagnosis and management will help minimize the biological and economic impact of an Argulus outbreak.

\section{Prevention}

Because of potential challenges with controlling this parasite, especially in food and pond fish, biosecurity measures should be instituted and followed to minimize introduction or transmission to other ponds, systems, or facilities (see UF EDIS Circular 120).

Incoming fish, particularly wild-caught or pond-raised stock, should be quarantined, observed, and sampled in order to minimize the risk of introduction. Argulus outbreaks, once recognized, should be managed quickly. Source water should be evaluated to ensure that is not a pathway for introduction of argulid eggs. Ideally, water should be filtered or obtained from a fish-free and Argulusfree source.

\section{Summary}

Argulus infestations are not uncommon in wild or pondraised freshwater and marine fish. Because infections can rapidly escalate, causing disease and mortalities, management and treatment are recommended as soon as Argulus is identified. While several effective treatments are possible, availability, legalities, logistics and fish species' sensitivities should be considered. The best way to avoid an Argulus infestation is through good biosecurity, including screening and quarantine of incoming fish, and continuous observation of all fish.

\section{References and Suggested Reading}

Hakalahti-Siren, T., V. M. Mikheev, and E. T. Valtonen. 2008. Control of freshwater fish louse Argulus coregoni: a step toward an integrated management strategy. Diseases of Aquatic Organisms 82: 67-77.

Hanson S. K., J. E. Hill, C. A. Watson, R. P. Yanong, and R. Endris. 2011. Evaluation of emamectin benzoate for the control of experimentally induced infestations of
Argulus sp. in goldfish and koi carp. J Aquat Anim Health. 23(1):30-34.

Hoffman, G. L. 1977. Argulus, a branchiuran parasite of freshwater fishes. US Fish and Wildlife Services Fish Disease Leaflet 49: 1-9.

Hoffman, G. L. 1999. Parasites of North American freshwater fishes. Cornell University Press, Ithaca, NY.

Kabata, Z. 1985. Parasites and diseases of fish cultured in the tropics. Taylor \& Francis, London and Philadelphia, PA.

Lester, R. J. G. and C. J. Hayward. 2006. Phylum Arthropoda. Pg. 466-565 in P. T. K. Woo, editor. Fish diseases and disorders Vol 1: Protozoan and Metazoan Infections, 2nd ed. CAB international, London, England.

Longshaw, M. and S.W. Feist. 2001. Parasitic diseases. Pg. 167-183 in W. H. Wildgoose, editor. BSAVA manual of ornamental fish, $2^{\text {nd }}$ ed. British Small Animal Veterinary Association, Gloucester, England.

Noga, E. J. 2010. Fish Disease: Diagnosis and Treatment, $2^{\text {nd }}$ ed. Wiley-Blackwell, Ames, Iowa.

Pasternak, A. F., V. N. Mikheev, and E. T. Valtonen. 2000. Life history characteristics of Argulus foliaceus L. (Crustacea: Branchiura) populations in Central Finland. Ann. Zool. Fennici 37: 25-35.

Rushton-Mellor, S. K. and G. A. Boxshall. 1994. The developmental sequence of Argulus foliaceus (Crustacea: Branchiura). Journal of Natural History 28(4): 763-785.

Shafir, A. and J. G. van As. 1986. Laying, development and hatching of eggs of the fish ectoparasite Argulus japonicus (Crustacea: Branchiuria). Journal of Zoology 210: 401-414.

Stoskopf, M. K. 1993. Fish medicine. W.B. Saunders Company, Philadelphia, PA.

Yanong, R. P. E. UF/IFAS Circular 120 Fish Health Management Considerations in Recirculating Aquaculture Systems - Part 1: Introduction and General Principles. http://edis. ifas.ufl.edu/FA099. Accessed November 12, 2012. 
Archival copy: for current recommendations see http://edis.ifas.ufl.edu or your local extension office. 